\section{Biocompatibility of a Calcium Hydroxide-Propolis Experimental Paste in Rat Subcutaneous Tissue}

\author{
Graziela Garrido Mori ${ }^{1}$, Sindineia da Silva Rodrigues², Sheila Tieko
}

Shibayama ${ }^{2}$, Marcelo Pomini ${ }^{1}$, Cristhiane Olivia Ferreira do Amaral $^{3}$

\author{
'Discipline of Endodontics, Presidente \\ Prudente School of Dentistry, \\ UNOESTE - University of Western São \\ Paulo, Presidente Prudente, SP, Brazil \\ ${ }^{2}$ Presidente Prudente School of \\ Dentistry, UNOESTE - University \\ of Western São Paulo, Presidente \\ Prudente, SP, Brazil \\ ${ }^{3}$ Discipline of Pediatric Dentistry, \\ Presidente Prudente School of \\ Dentistry, UNOESTE - University \\ of Western São Paulo, Presidente \\ Prudente, SP, Brazil
}

Correspondence: Profa. Dra. Graziela Garrido Mori, Rua Claudionor Sandoval, 1305, 19023-200 Presidente Prudente, SP, Brasil. Tel: +55-18-3229-1000. e-mail: grazielagm@hotmail.com

Key Words: biocompatibility, calcium hydroxide, Endodontics, propolis.

\section{Introduction}

Calcium hydroxide $(\mathrm{CH})$ is the material of choice for intracanal medication in Endodontics $(1,2)$, and its effects include antimicrobial activity (1-4), capacity to limit root resorption $(2,5,6)$ and promotion of periapical repair $(2,4)$. Different substances, like distilled water, saline and propylene glycol have been combined with $\mathrm{CH}$ powder to prepare pastes $(1,2,4,7)$ to obtain a material with adequate consistency and enhanced antimicrobial capacity.

Propolis is a natural, non-toxic resinous substance produced by honeybees from products collect from several types of plants and used for sealing and protection of beehives (8). It has recognized anti-inflammatory (8), antimicrobial (8-12), antifungal (8-10) and scar-healing properties $(8,10,13)$. Because of its excellent characteristics, propolis has been suggested as an intracanal medication in Endodontics $(11,12)$.

de Rezende et al. (14) evaluated the antimicrobial capacity of a $\mathrm{CH}$ and propolis pastes: paste 1 (propolis ethanol extract $+\mathrm{CH}$ ) and paste 2 (non-alcoholic propolis extract $+\mathrm{CH}$ ). The authors observed that the pastes were effective, with larger zones of microbial growth inhibition around paste 2. Montero and Mori (15) demonstrated the diffusion capacity of a $\mathrm{CH}$ and propolis paste through the dentinal tubules, suggesting its use as an intracanal medication.

Although the antimicrobial capacity and transdentinal diffusion of the paste have been demonstrated, evaluation of its biocompatibility with the tissues is fundamental. This study evaluated the biocompatibility of a experimental paste of $\mathrm{CH}$ and propolis in the subcutaneous tissue of rats. The biocompatibility was determined according to the inflammatory reaction in contact with the experimental paste compared with empty tube (negative control) and zinc oxide (positive control).

\section{Material and Methods}

The study was approved by UNOESTE Institutional Review Board on Animal Experimentation (Protocol \#542).

Fifteen male Wistar rats (Rattus norvegicus, albinus) weighing 180-200 g were used. During the study, the animals were kept in cages identified according to the group and study period. The animals were fed solid ration, except for the preoperative $12 \mathrm{~h}$, and had water ad libitum.

For surgical interventions, the animals were anesthetized with a combination of ketamine hydrochloride (Dopalen; Sespo Indústria e Comércio Ltda, Paulínia, SP, Brazil) and xylazine hydrochloride (Anasedan; Agribrands do Brasil 
Ltda, Paulínia, SP, Brazil) by intramuscular injection, at a dose of $0.05 \mathrm{~mL} / 100 \mathrm{~g}$ weight for each substance. Anesthesia was delivered using a disposable insulin syringe.

Thereafter, 60 sterile polyethylene tubes with $1.3 \mathrm{~mm}$ internal diameter and $10 \mathrm{~mm}$ length were selected and divided in three groups: Negative control $(N C ; n=15)$ : the polyethylene tubes were kept empty; Positive control (PC; $n=15$ ): the polyethylene tubes were filled with zinc oxide and eugenol, prepared according to the manufacturer's instructions (Biodinâmica, Lobato, PR, Brazil); Experimental group ( $E G ; n=30)$ : the polyethylene tubes were filled with the experimental paste prepared with $1 \mathrm{~g}$ of $\mathrm{CH}$ powder (Biodinâmica) and $2 \mathrm{~mL}$ of $11 \%$ non-alcoholic propolis (Apis Flora, Ribeirão Preto, SP, Brazil). Size $15 \mathrm{~K}$-files were used to deliver the material inside the tube and pediatric excavators were used for material condensation. The tubes were completely filled with the materials.

The back of the animals was shaved and cleaned with 0.12\% chlorhexidine (Periogard; Pfizer Ltda, Santo Amaro, $\mathrm{SP}$, Brazil). Two incisions were made in the median dorsal region (upper and lower regions of the dorsum) using a \# 15 scalpel blade (Embramac Exportação e Importação, Itapira, SP, Brazil). Lateral to the incisions, the cutaneous tissue was pinched and the tissue was dissected using blunt-end scissors. The tubes were then introduced in the subcutaneous tissue. Each animal received four tubes, two in the upper region of the dorsum (NC on the right of the incision and EG on the left) and two tubes in the lower region of the dorsum (PC on the left of the incision and EG on the right). The border of the incisions were sutured with nylon 5-0 (Ethicon; Johnson \& Johnson, São José dos Campos, SP, Brazil).

After 7, 14 and 30 days, 5 animals were euthanized by anesthetic overdose. The tissues containing the tubes were removed and fixed in 10\% neutral formalin for 48 $h$. The tubes were then removed from the tissue and the specimens were embedded in paraffin. Longitudinal sections $5-\mu \mathrm{m}$ thick were obtained at every $50 \mu \mathrm{m}$, adding up to 12 sections per specimen. The sections were stained with hematoxylin and eosin and analyzed by light microscopy.

The histological sections were analyzed considering the presence and type of inflammatory process, proliferation of connective tissue or occurrence of destructive processes, as abscesses or tissue necrosis. The intensity of the inflammatory process was classified by established scores, varying according to the intensity of the inflammatory process: score 1 = non-significant; score 2 = mild; score 3 $=$ moderate; score $4=$ severe. The criterion for classification of different degrees of inflammation and tissue reaction was established following standardized recommendations for biological evaluation of dental materials (16).

Scores were assigned by an experienced blinded examiner and organized in specific sheets. Data were analyzed statistically by Tukey's test at 5\% significance level.

\section{Results}

\section{Negative Control (Empty Tube)}

The analysis of histological sections confirmed the biocompatibility of the empty tube with the connective tissue. At 7 days, there were poorly organized collagen fibers and young fibroblasts. Small areas exhibited neutrophils and clotting regions. Inflammation was non-significant in most sections (Fig. 1A). At 14 and 30 days, the connective tissue was well organized, with collagen fibers, fibroblasts and blood vessels (Fig. 1B,C). In several sections, especially at 30 days, there was great proliferation of dense connective tissue toward the inner part of the tube.

The analysis of scores did not demonstrate statistically significant differences in relation to the inflammatory process among the study periods.

\section{Positive Control (Zinc Oxide-Eugenol Paste)}

Microscopic analysis of histological sections confirmed the irritability of zinc oxide-eugenol with the connective tissue. The inflammation was moderate or severe in most sections, without statistically significant difference between the study periods.

At 7 days, there was great quantity of blood clots and inflammatory cells, especially neutrophils (Fig. 1D). Some abscess areas were observed. Some sections exhibited poorly organized collagen fibers and young fibroblasts. At 14 and 30 days, the connective tissue was better organized, with presence of collagen fibers, fibroblasts and blood vessels; however, a large number of neutrophils and macrophages was observed (Figs. 1E, F).

\section{Experimental Group (CH and Propolis)}

At 7 days, the histological sections were characterized by the presence of young collagen fibers, some fibroblasts, clot areas and proliferating blood vessels. The inflammatory process was present in several sections; in some of them, inflammation was moderate to severe, with great quantity of neutrophils (Fig. 1G).

At 14 days the inflammation was reduced, insignificant or mild in most sections. Some sections exhibited lymphocytes and macrophages, characterizing moderate inflammation. Onset of connective tissue formation with collagen fibers, fibroblasts and blood vessels was also observed (Fig. 1H).

At 30 days, there was great formation of dense connective tissue, with mature fibroblasts, organized collagen fibers and few blood vessels (Fig. 1I). In some sections, tissue proliferating toward the interior of the tube was observed. Inflammation was insignificant or 
mild in most sections; some presented inflammatory cells characterizing moderate inflammation.

Comparison of scores in this group revealed statistically significant difference between 7 and 30 days $(p<0.05)$, confirming the reduction of the inflammatory process.

Comparison between NC and PC revealed statistically significant difference in all study periods $(p<0.05)$ (Table 1$)$, indicating the difference in tissue response to the materials.

$\mathrm{PC}$ at 7 days was different from NC in all study periods and from PC at 30 days. PC at 14 and 30 days was significantly different from $\mathrm{NC}$, in all study periods
(Table 1). This demonstrates that the experimental paste was irritating at 7 days, but it was biocompatible at 14

Table 1. Mean scores and statistical differences within the groups according to the experimental times

\begin{tabular}{lccc}
\hline Period & $\begin{array}{c}\text { Negative } \\
\text { control }\end{array}$ & $\begin{array}{c}\text { Positive } \\
\text { control }\end{array}$ & $\begin{array}{c}\text { Experimental } \\
\text { paste }\end{array}$ \\
\hline 7 days & $1.40 \mathrm{a}$ & $3.40 \mathrm{~b}, \mathrm{c}$ & $2.53 \mathrm{~b}, \mathrm{c}, \mathrm{f}$ \\
14 days & $1.27 \mathrm{a}$ & $3.07 \mathrm{~b}, \mathrm{c}, \mathrm{e}$ & $1.87 \mathrm{~d}, \mathrm{f}$ \\
30 days & $1.07 \mathrm{a}$ & $3.60 \mathrm{~b}, \mathrm{e}$ & $1.60 \mathrm{~d}, \mathrm{f}$ \\
\hline a,c,e with statistically significant difference from b,d,f.
\end{tabular}
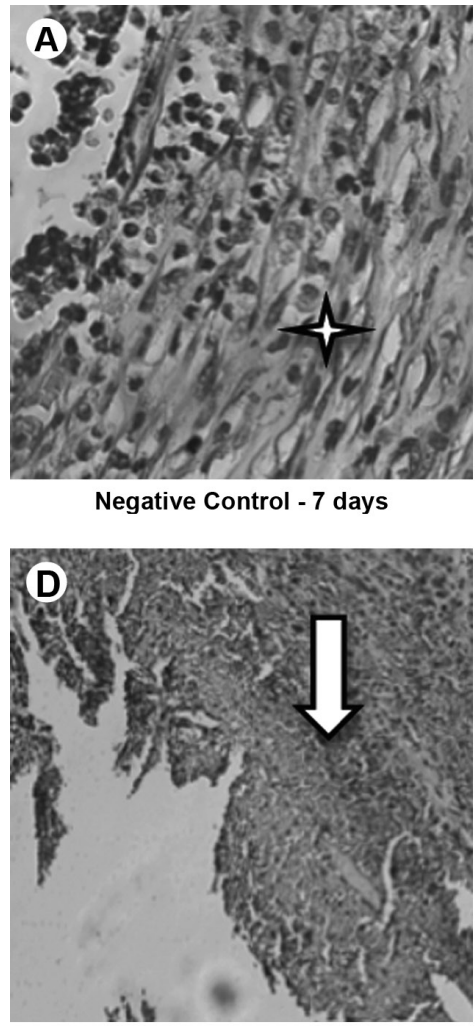

Positive Control - 7 days

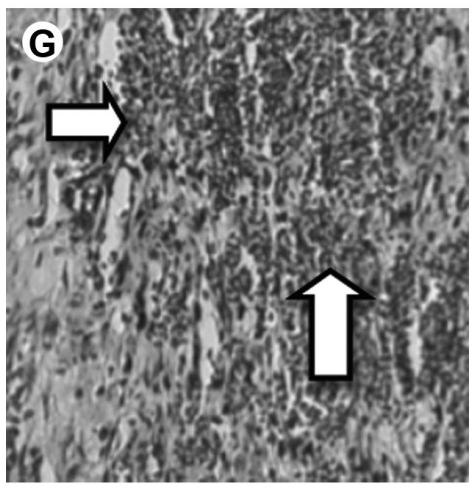

Experimental Paste - 7 days

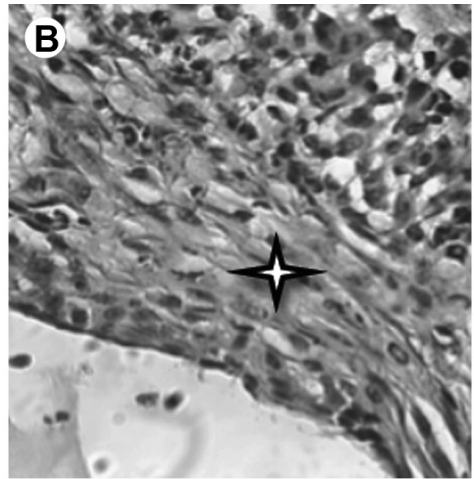

Negative Control - 14 days

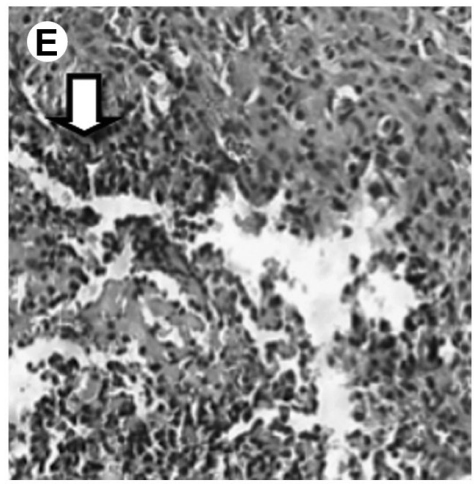

Positive Control - 14 days

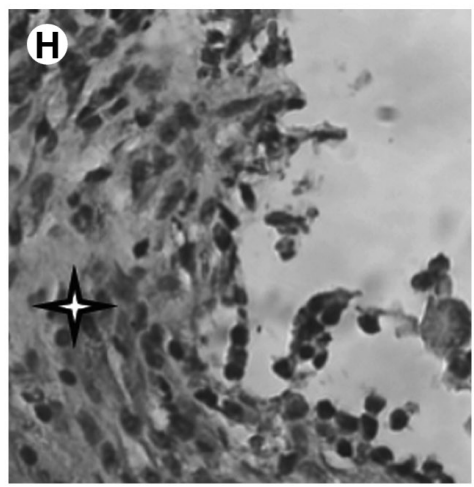

Experimental Paste - 14 days

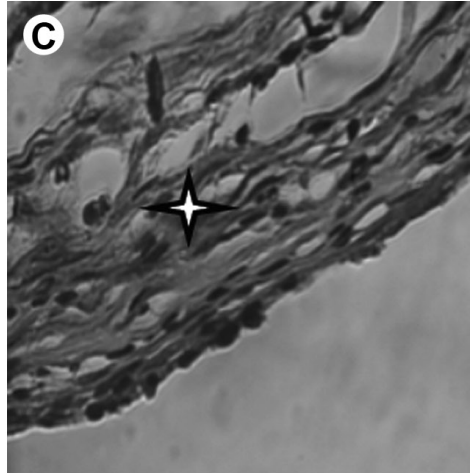

Negative Control - 30 days

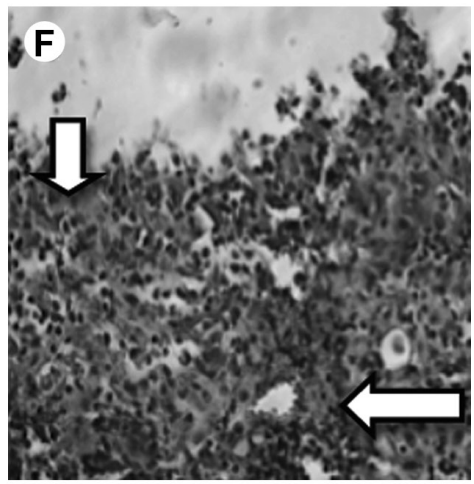

Positive Control - 30 days

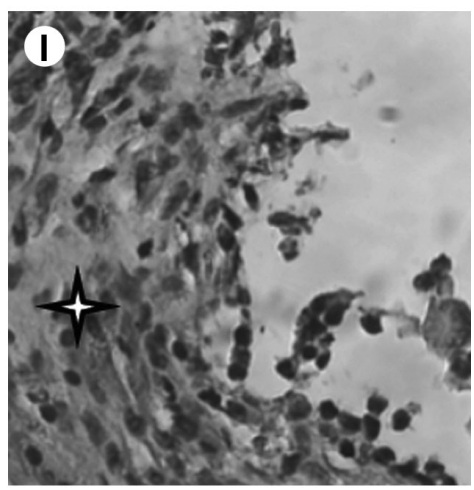

Experimental Paste $\mathbf{-} 30$ days

Figure 1. Histological features according to groups and experimental times. HE, Original magnification 40x. A,B,C: Connective tissue with absence of inflammatory process (stars) in the negative control group at 7, 14 and 30 days, respectively. D,E,F: Connective tissue with inflammatory process (arrows) in the positive control group at 7, 14 and 30 days, respectively. G: Connective tissue with inflammatory process (arrows) in the experimental paste group at 7 days. $\mathrm{H}, \mathrm{l}$ : connective tissue with absence of inflammatory process (stars) in the experimental paste group at 14 and 30 days, respectively. 
and 30 days.

\section{Discussion}

The compatibility of dental materials with living tissues is fundamental to avoid risk for the patients (17). Biocompatibility is the ability of materials to avoid inadequate responses in use $(17,18)$. Several tests may be used to evaluate the reaction of cells and tissues to the presence of materials $(17,18)$, the most common being cytotoxicity assays, genotoxicity assays, bone implants and subcutaneous implants (17). Even though the cytotoxicity assays are faster, their results may not be extrapolated to the clinical practice (17).

According to the American Dental Association (19) and the Fédération Dentaire Internationale (20), the implantation method is considered a valid test to investigate the biocompatibility of materials. More specifically, implantation of materials in the subcutaneous tissue of small animals like rats is considered a reliable and adequate test to evaluate the biocompatibility of materials $(17,18,21$ 23). The material may be introduced in the tissues inside polyethylene tubes (17). The use of tubes is recommended because they are not irritant to the tissues $(17,18,22-25)$ and prevent material diffusion in the tissues, simulating the clinical conditions of medications applied in the root canal (23).

A biocompatible material should present low toxicity without promoting inflammatory reaction $(16,18,21)$, which should be insignificant when present $(16,18,21)$. Silveira et al. (22) stated that a material is considered biocompatible if the inflammatory reaction is reduced to insignificant along with time.

In the present study, empty tube served as negative control because it is an inert material and allows for the formation of connective tissue in contact with its surface (22-25). Zinc oxide-eugenol paste served as positive control because it is known as an irritating material for the tissues. The irritating potential of zinc oxide-eugenol has been extensively demonstrated, characterized by the formation of areas of tissue destruction and presence of severe inflammation $(18,22,24,25)$ and discrete presence of newly formed connective tissue (24). The results of the present study are similar to previous findings, since the inflammation levels were minimal in NC and high in PC. Great formation of connective tissue was observed in NC and the opposite scenario was observed in PC.

Comparison between control and experimental groups showed that the experimental paste was irritating to the tissues at 7 days, which was not observed at 14 and 30 days. According to Hauman and Love (17), $\mathrm{CH}$ is a well-tolerated material in the periapical region, and some inflammatory reaction may be observed in the first two weeks after contact with the tissues. Silveira et al. (22) considers a material as biocompatible if the inflammatory reaction is significantly reduced with time. Thus, it may be considered that the $\mathrm{CH}$ and propolis paste was biocompatible with the rat connective tissue, since the inflammatory reaction observed in the initial period was significantly reduced with time $(p<0.05)$. Also, newly formed connective tissue was observed in the area contacting the experimental paste, which corroborates the absence of irritating stimlus.

Considering the present results, it was concluded that the tested experimental paste was biocompatible. This characteristic combined with its antimicrobial action (14) and capacity to diffuse through the dentinal tubules (15), support its indication as an intracanal medication. Further confirmatory in vivo studies as well as studies on necrotic teeth and/or with periapical lesions should be conducted to substantiate the clinical use of this paste.

\section{Resumo}

Medicações intracanais são fundamentais para a desinfecção do sistema de canais radiculares e para a participação no reparo, a biocompatibilidade dos medicamentos deve ser considerada para não danificar os tecidos. Assim, esse estudo avaliou a biocompatibilidade de pasta experimental de hidróxido de cálcio associado à própolis em tecido subcutâneo de rato. Esse estudo foi conduzido em 15 ratos machos. Duas incisões foram feitas na região dorsal de cada animal para a introdução de 4 tubos. Um tubo estava vazio, um tubo tinha óxido de zinco e eugenol e os outros foram preenchidos com pasta experimental. Após 7, 14 e 30 dias, os animais foram mortos e os espécimes foram submetidos a preparação histotécnica. Os cortes histológicos foram analisados em microscópio de luz. Escores foram estabelecidos de acordo com o processo inflamatório e comparados estatisticamente por meio do teste de Tukey $(p<0,05)$. A análise dos cortes histológicos evidenciou insignificante ou discreta presença de reação inflamatória em contato com o tubo vazio em todos os períodos estudados, enquanto que o tecido conjuntivo em contato com o óxido de zinco e eugenol mostrou inflamação moderada ou severa sem diferença ao longo dos períodos estudados. 0 tecido conjuntivo estava com inflamação moderada aos 7 dias quando em contato com a pasta; no entanto, aos 14 e 30 dias, o processo inflamatório foi discreto ou insignificante. A pasta experimental foi biocompativel com os tecidos após o $14^{\circ}$ dia.

\section{Reference}

1. Mori GG, Ferreira FC, Batista FR, Godoy AM, Nunes DC. Evaluation of the diffusion capacity of calcium hydroxide pastes through the dentinal tubules. Braz Oral Res 2009;23:113-118.

2. Mohammadi Z, Dummer PM. Properties and applications of calcium hydroxide in Endodontics and dental traumatology. Int Endod J 2011;44:697-730.

3. Lima RK, Guerreiro-Tanomaru JM, Faria-Júnior NB, Tanomaru-Filho M. Effectiveness of calcium hydroxide-based intracanal medicaments against Enterococcus faecalis. Int Endod J 2012;45:311-316.

4. Duarte MA, Demarchi AC, Giaxa MH, Kuga MC, Fraga SC, de Souza LC. Evaluation of $\mathrm{pH}$ and calcium ion release of three root canal sealers. J Endod 2000;26:389-390.

5. Mori GG, Garcia RB, Gomes de Moraes I, Bramante CM, Bernardineli N Morphometric and microscopic evaluation of the effect of a solution of alendronate as an intracanal therapeutic agent in rat teeth submitted to late reimplantation. Dent Traumatol 2007;23:218-221.

6. Tronstad L, Andreasen J0, Hasselgren G, Kristerson L, Riis I. pH changes in dental tissues after root canal filling with calcium hydroxide. J Endod 
$1981 ; 7: 17-21$.

7. Zmener 0 , Pameijer $\mathrm{CH}$, Banegas $\mathrm{G}$. An in vitro study of the $\mathrm{pH}$ of three calcium hydroxide dressing materials. Dent Traumatol 2007;23:21-25.

8. Burdock GA. Review of the biological properties and toxicity of bee propolis. Food Chem Toxicol 1998;36:347-363.

9. Kujungiev A, Tsvetkova I, Serkedjieva Y, Bankova V, Christov R, Popov S. Antibacterial, antifungal, and antiviral activity of Propolis of different geographic origins. J Ethnopharmacol 1999;64:235-240.

10. Al-Shaher A, Wallace J, Agarwal S, Bretz W, Baugh D. Effect of propolis on human fibroblasts from the pulp and periodontal ligament. J Endod 2004;30:359-361.

11. Kayaoglu G, Ömürlü H, Akca G, Gürel M, Gençay Ö, Sorkun K, et al.. Antibacterial activity of Propolis versus conventional endodontic disinfectants against Enterococcus faecalis in infected dentinal tubules. J Endod 2011;37:376-381.

12. Madhubala MM, Srinivasan N, Ahamed S. Comparative evaluation of propolis and triantibiotic mixture as an intracanal medicament against Enterococcus faecalis. J Endod 2011;37:1287-1289.

13. Mori GG, Nunes DC, Castilho LR, de Moraes IG, Poi WR. Propolis as storage media for avulsed teeth: microscopic and morphometric analysis in rats. Dent Traumatol 2010;26:80-85.

14. de Rezende GP, da Costa LR, Pimenta FC, Baroni DA. In vitro antimicrobial activity of endodontic pastes with propolis extracts and calcium hydroxide: a preliminary study. Braz Dent J 2008;19:301-305.

15. Montero JC, Mori GG. Assessment of ion diffusion from a calcium hydroxide-propolis paste through dentin. Braz Oral Res 2012;26:318322.

16. Stanford JW. Recommended standard practices for biological evaluation of dental materials. London: Fédération Dentaire Internationale; 1980.

17. Hauman $\mathrm{CHJ}$, Love RM. Biocompatibility of dental materials used in contemporary endodontic therapy: a review. Part 1. Intracanal drugs and substances. Int Endod J 2003;36:75-85.

18. Hauman $\mathrm{CH}$, Love RM. Biocompatibility of dental materials used in contemporary endodontic therapy: a review. Part 2. Root-canal-filling materials. Int Endod J 2003;36:147-160.

19. American Nacional Standards/American Dental Association. Document no. 41 for recommended standard practices for biological evaluation of dental materials. New York: ANSI/ ADA; 1982.

20. International Organization for Standardization. ISO 7405 Dentistry - preclinical evaluation of biocompatibily of medical devices used in dentistry - test methods of dental materials. Genève: ISO; 1997.

21. Mori GG, de Moraes IG, Nunes DC, Castilho LR, Poi WR, Capaldi ML. Biocompatibility evaluation of alendronate paste in rat's subcutaneous tissue. Dent Traumatol 2009;25:209-212.

22. Silveira CM, Pinto SC, Zedebski Rde A, Santos FA, Pilatti GL. Biocompatibility of four root canal sealers: a histopathological evaluation in rat subcutaneous connective tissue. Braz Dent J $2011 ; 22: 21-27$

23. Shahi S, Rahimi S, Lotfi M, Yavari H, Gaderian A. A comparative study of the biocompatibility of three root-end filling materials in rat connective tissue. J Endod 2006;32:776-780.

24. Scarparo RK, Grecca FS, Fachin EV. Analysis of tissue reactions to methacrylate resin-based, epoxy resin-based, and zinc oxide-eugenol endodontic sealers. J Endod 2009;35:229-232.

25. Mori GG, Teixeira LM, de Oliveira DL, Jacomini LM, da Silva SR. Biocompatibility evaluation of biodentine in subcutaneous tissue of rats. J Endod 2014 [Epub ahead of print. DOI: 10.1016/j. joen.2014.02.027].
Received April 9, 2013 Accepted February 25, 2014 